\title{
Dietary effects of Ca-zeolite supplementation on some blood and tibial bone characteristics of broilers
}

\author{
Hasan Eleroğlu ${ }^{1 \#}$, Hüseyin Yalçın ${ }^{2} \&$ Arda Yıldırım ${ }^{3}$ \\ ${ }^{1}$ Cumhuriyet University, Şarkışla Așık Veysel Vocational High School, Sivas, Turkey \\ ${ }^{2}$ Cumhuriyet University, Engineering Faculty, Department of Geological Engineering, Sivas, Turkey \\ ${ }^{3}$ Gaziosmanpaşa University, Agriculture Faculty, Department of Animal Science, Tokat, Turkey
}

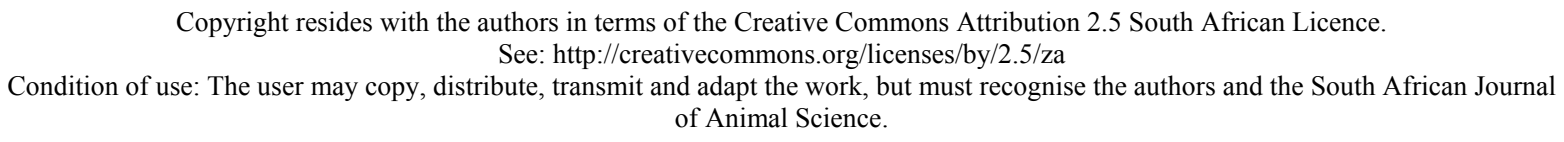

\begin{abstract}
This study was conducted to investigate the effects of differing amounts of natural Ca-zeolite on bone and some blood parameters. A total of 240 day-old Ross 308 broiler chicks were assigned to four treatments with three replicates, each containing 20 day-old chicks of mixed sex. A clinoptilolite+mordenite type of zeolite was added in the broiler diets at levels of $0 \mathrm{~g} / \mathrm{kg}, 10 \mathrm{~g} / \mathrm{kg}, 30 \mathrm{~g} / \mathrm{kg}$, and $50 \mathrm{~g} / \mathrm{kg}$. Stocking density was 14 broilers $/ \mathrm{m}^{2}$. During the six-week trial, blood parameters and bone characteristics were monitored. The inclusion of Ca-zeolite, at various levels, did not have any significant effect on the concentration of blood serum biochemical parameters; serum glucose, cholesterol, total protein, uric acid; concentrations of $\mathrm{Ca}, \mathrm{P}$, $\mathrm{Na}, \mathrm{K}, \mathrm{Cl}$, and on tibial bone characteristics (tibia weight, ash, volume, specific gravity, and $\mathrm{Ca}$ and $\mathrm{P}$ contents) in the two sexes and mixed-sex between the groups at 21 and 42 days of age.
\end{abstract}

Keywords: Clinoptilolite+mordenite, serum biochemistry, tibia parameters

\#Corresponding author: eleroglu@cumhuriyet.edu.tr

\section{Introduction}

Zeolites are important minerals of hydrated aluminotectosilicates of alkali and alkaline-earth cations with three-dimensional structures of interconnecting channels and large pores, capable of trapping molecules in proper conditions. Each zeolite species has its own unique crystal structure and, hence, its own set of chemical and physical properties. Among many properties attributed to zeolites, most characteristics that relate to their effectiveness in animal nutrition are their ability to lose or gain water alternatively, and being capable of exchanging a variety of cations selectively without much major changes in their structure (Mumpton \& Fishman, 1977; Waldroup et al., 1984; Elliot \& Edwards, 1991; Mumpton, 1999; Shariatmadari, 2008; Safaeikatouli et al., 2010).

Zeolites have cationic binding features that could protect animals from the tissue accumulation of toxic materials (Pond \& Yen, 1983; Jain, 1999) and influence Ca and P utilization (Leach et al., 1990; Watkins \& Southern, 1991; Frost et al., 1992). Beneficial effects may also be attributed to the $\mathrm{Si}, \mathrm{Al}$ or $\mathrm{Na}$ content of zeolites because it has been established that these minerals can influence Ca-metabolism (Edwards, 1987; Öztürk et al., 1998) and bind nitrogenous cations such as $\mathrm{NH}_{4}{ }^{+}$(Nakaue et al., 1981). It has also been suggested that zeolites may selectively retain or release $\mathrm{Ca}$ as it passes through the digestive system (Quarles, 1985; Roland et al., 1985) and that they can absorb the nitrogen of some amino acids and stabilize them, thus reducing the energy required for the production of meat.

Previous studies, in different animal diets, indicated that the dietary supplements of zeolites had no major effect on serum biochemistry. Supplementing broiler diets with hydrated NaCaAl-silicate (Dwyer et al., 1997; Başalan et al., 2005; Miles \& Henry, 2007) and with NaAl-silicate (Kurtoğlu et al., 1998), compared with hydrated NaCaAl-silicate, bentonite, and polyvinylpolyprolidone (Keçeci et al., 1998), and with Na-bentonite (Santurio et al., 1999; Tauqir \& Nawaz, 2001; Tauqir et al., 2001; Eraslan et al., 2005) did not affect most of the serum biochemical parameters. 
The effects of dietary zeolites in poultry have been investigated extensively and a growth-promoting effect, evident in mineral utilization and metabolism has been reported. The beneficial effects may be related to the $\mathrm{Al}, \mathrm{Si}, \mathrm{Zn}, \mathrm{Na}$ or $\mathrm{K}$ concentrations of zeolite, because these minerals have been shown to influence mineral metabolism and electrolyte balance, leading to an increased formation of bone (Roland et al., 1993; Utlu et al., 2007). Mineral metabolism and electrolyte balance largely regulate bone formation that would be linked to their primary action on mineral absorption, tissue distribution and excretion (Watkins \& Southern, 1991). On the other hand, it has also been reported that zeolites suppressed P utilization by forming an indigestible compound with $\mathrm{P}$ through its aluminosilicate component, increased $\mathrm{Ca}$ utilization (Elliot \& Edwards, 1991) and had an indirect effect on $\mathrm{P}$ absorption and metabolism (Leach et al., 1990). Although several studies claimed that the addition of zeolites increased $\mathrm{Ca}$ utilization and the rate of bone ash deposition during growth (Watkins \& Southern, 1991; 1992; Ballards \& Edwards, 1988; Debeic, 1994; Zhang \& Hung 1992; Rabon et al., 1995), other researchers reported no zeolite effect (Altan et al., 1998; Elliot \& Edwards, 1991; Gezen \& Eren, 2002; Keshavarz \& Mccormick, 1991). Moreover, the extent of performance-enhancement effects has been attributed to the type of zeolite used, its purity and physicochemical adsorption properties as well as the supplementation level used in the diet (Papaioannou et al., 2005; Tiwari, 2007).

It is well established that the health and performance of birds are influenced by the nutrient and metabolites of blood that can be estimated by understanding the relationships between bone characteristics and blood biochemical parameters. The purpose of this study was, therefore, to evaluate the changes of some blood serum biochemical and bone characteristics of broilers with different levels of zeolite in their diet.

\section{Materials and Methods}

The zeolite used in this study was collected from well-defined zeolitic stratigraphic units in the SivasYavu region of Turkey (Yalçın, 1997). Mineralogical associations were carried out on bulk samples by means of a Rigaku DMAX IIIC automated diffractometer at the Cumhuriyet University, Sivas. The material added to the basal diet during this investigation comprised mainly of clinoptilolite $(50 \%)$, mordenite $(40 \%)$, quartz (5\%), feldspar (5\%) and trace amounts of smectitic clay. The X-ray diffraction pattern and morphologies of the zeolite were fully explained in another study (Eleroğlu \& Yalçın, 2005). The samples were analyzed at the Activation Laboratories Ltd. (Actlabs, Ancaster, Canada) for major oxides and trace element content, using an inductively coupled plasma mass spectrometer (ICP-MS).

The $\mathrm{SiO}_{2}, \mathrm{Al}_{2} \mathrm{O}_{3}, \mathrm{H}_{2} \mathrm{O}$ related to loss on ignition, and $\mathrm{CaO}$ are the essential components of the zeolitic material and $\mathrm{Fe}_{2} \mathrm{O}_{3}$ and $\mathrm{MgO}$ are represented in minor amounts (Table 1). Heulandite and mordenite-bearing tuffs are richer in alkaline-earth elements such as $\mathrm{Ca}$, negligible $\mathrm{Sr}$ and $\mathrm{Ba}$ rather than alkali ones such as $\mathrm{Na}$ and $\mathrm{K}$. The ratios of $\mathrm{SiO}_{2} /\left(\mathrm{Al}_{2} \mathrm{O}_{3}+\mathrm{Fe}_{2} \mathrm{O}_{3}\right),\left(\mathrm{Na}_{2} \mathrm{O}+\mathrm{K}_{2} \mathrm{O}\right) /(\mathrm{CaO}+\mathrm{BaO}+\mathrm{SrO})$ and $\mathrm{Na}_{2} \mathrm{O} / \mathrm{K}_{2} \mathrm{O}$ are 4.68, 0.35 and

Table 1 Chemical composition of the natural zeolitic volcanic tuff

\begin{tabular}{lr|rr|rr}
\hline \multicolumn{2}{l|}{ Major oxides (wt. \%) } & \multicolumn{4}{|c}{ Trace Elements (mg/kg) } \\
\hline $\mathrm{SiO}_{2}$ & 63.82 & $\mathrm{Cr}$ & 60 & $\mathrm{Sb}$ & 1 \\
$\mathrm{TiO}_{2}$ & 0.297 & $\mathrm{Ni}$ & 20 & $\mathrm{Rb}$ & 17 \\
$\mathrm{Al}_{2} \mathrm{O}_{3}$ & 11.72 & $\mathrm{Co}$ & 3 & $\mathrm{Ba}$ & 1255 \\
$\Sigma \mathrm{Fe}_{2} \mathrm{O}_{3}$ & 1.92 & $\mathrm{Sc}$ & 7 & $\mathrm{Sr}$ & 3571 \\
$\mathrm{MnO}$ & 0.022 & $\mathrm{~V}$ & 31 & $\mathrm{Ga}$ & 13 \\
$\mathrm{MgO}$ & 1.04 & $\mathrm{Cu}$ & 10 & $\mathrm{Nb}$ & 10 \\
$\mathrm{CaO}$ & 4.11 & $\mathrm{~Pb}$ & 22 & $\mathrm{Hf}$ & 5 \\
$\mathrm{Na} \mathrm{N}_{2} \mathrm{Or}$ & 0.95 & $\mathrm{Zn}$ & 40 & $\mathrm{Zr}$ & 194 \\
$\mathrm{~K}_{2} \mathrm{O}$ & 0.67 & $\mathrm{Sn}$ & 4 & $\mathrm{Y}$ & 30 \\
$\mathrm{P}_{2} \mathrm{O}_{5}$ & 0.07 & $\mathrm{~W}$ & 1 & $\mathrm{Th}$ & 13 \\
$\mathrm{LOI}$ & 14.84 & $\mathrm{As}$ & 9 & $\mathrm{U}$ & 2 \\
\hline
\end{tabular}

$\Sigma \mathrm{Fe}_{2} \mathrm{O}_{3}=$ Total iron, $\mathrm{LOI}=$ Loss on ignition at $1000^{\circ} \mathrm{C}$. 
Table 2 Ingredients and composition of experimental diets (\%)

\begin{tabular}{|c|c|c|c|c|}
\hline Feed ingredients & $0-11$ days & 11-21 days & 21-35 days & 35-42 days \\
\hline Maize & 54.1 & 55.3 & 57.7 & 61.7 \\
\hline Soybean meal & 16.2 & 11.5 & 8.2 & 4.2 \\
\hline Full-fat soybean & 16 & 20 & 21 & 21 \\
\hline Chicken meal & 3.9 & 3.9 & 3.9 & 3.9 \\
\hline Sunflower meal & 3 & 3 & 3 & 3 \\
\hline Meat-bone meal & 2.6 & 2.6 & 2.6 & 2.6 \\
\hline Vegetable oil & 1.11 & 2.18 & 2.30 & 2.48 \\
\hline Fish meal & 1 & - & - & - \\
\hline Marble powder & 0.60 & 0.52 & 0.43 & 0.25 \\
\hline Vitamin-mineral premix* & 0.30 & 0.25 & 0.25 & 0.25 \\
\hline DL-Methionine & 0.27 & 0.21 & 0.15 & 0.15 \\
\hline Lysine & 0.240 & 0.110 & 0.070 & 0.075 \\
\hline Salt & 0.10 & 0.10 & 0.12 & 0.11 \\
\hline Vitamin $\mathrm{D}_{3}$ & 0.100 & 0.075 & 0.040 & - \\
\hline Vitamin E & 0.05 & - & - & 0.10 \\
\hline Enzyme & 0.10 & 0.10 & 0.10 & 0.10 \\
\hline Sodium bicarbonate & 0.075 & 0.075 & 0.050 & 0.075 \\
\hline Choline chloride & 0.07 & 0.07 & 0.05 & 0.05 \\
\hline Anticoccidiostat & 0.05 & 0.05 & 0.05 & - \\
\hline Toxin binder & 0.05 & - & - & - \\
\hline \multicolumn{5}{|c|}{ Calculated nutrients composition $(\mathrm{g} / \mathrm{kg})$} \\
\hline $\mathrm{ME}(\mathrm{MJ} / \mathrm{kg})$ & 12.73 & 13.15 & 13.31 & 13.48 \\
\hline Crude protein & 230 & 215 & 205 & 190 \\
\hline Crude cellulose & 44.4 & 45.2 & 44.9 & 44.8 \\
\hline Crude ash & 60.7 & 57.1 & 54.3 & 51.0 \\
\hline Ether extract & 89.1 & 106.1 & 109.3 & 113.1 \\
\hline Lysine & 15 & 13 & 12 & 11 \\
\hline Methionine & 6.1 & 5.3 & 4.6 & 4.4 \\
\hline Methionine + Cystine & 10.8 & 9.8 & 9.0 & 8.6 \\
\hline Threonine & 9.8 & 8.8 & 8.4 & 7.8 \\
\hline Calcium & 10.5 & 9.5 & 9.0 & 8.0 \\
\hline Total phosphorus & 7.6 & 7.2 & 7.1 & 6.7 \\
\hline Available phosphorus & 5.0 & 4.6 & 4.6 & 4.3 \\
\hline
\end{tabular}

*Each kg of vitamin-mineral premix contained: vitamin A, 4.400.000 IU; vitamin $\mathrm{D}_{3}, 1.600 .000$ $\mathrm{IU}$; vitamin E, $20.000 \mathrm{mg}$; vitamin $\mathrm{K}_{3}, 1.600 \mathrm{mg}$; vitamin $\mathrm{B}_{1}, 1.200 \mathrm{mg}$; vitamin $\mathrm{B}_{2}, 3.200 \mathrm{mg}$; vitamin $\mathrm{B}_{3}, 20.000 \mathrm{mg}$; vitamin $\mathrm{B}_{5}, 6.000 \mathrm{mg}$; vitamin $\mathrm{B}_{6}, 1.600 \mathrm{mg}$; vitamin $\mathrm{B}_{9}, 800 \mathrm{mg}$; vitamin $\mathrm{B}_{12}, 8 \mathrm{mg}$; biotin, $80 \mathrm{mg}$; antioxidant dry, $50.000 \mathrm{mg}$; Cu, $6.000 \mathrm{mg}$; Fe, $20.000 \mathrm{mg}$; Mn, 48.000 $\mathrm{mg}$; Se, $80 \mathrm{mg}$; Zn, $40.000 \mathrm{mg}$; Co, 80 mg; I, $500 \mathrm{mg}$.

1.42, respectively, and can be classified as Ca-zeolite by extruding very small impurities. Besides, transition metals and other trace elements are present in negligible amounts in zeolites.

Two hundred and forty day-old sexed broiler chicks (Ross 308 strain) were obtained from a commercial hatchery (Kayseri Yemsel Company, Turkey). The birds were randomly allocated to 12 pens, each with 10 males and 10 females. There were four dietary treatments, each with three replicates. The 
experiment was conducted as a completely randomized design. Three maize-soybean meal basal diets (starter 0 - 11 days, grower $11-21$ - 35 days and finisher 35 - 42 days) were formulated to provide adequate levels of all nutrients for broilers (NRC, 1994; Table 2). The diets of the starter phase (0-11 days) were formulated to contain $230 \mathrm{~g}$ crude protein $(\mathrm{CP}) / \mathrm{kg}$ and $12.73 \mathrm{MJ}$ of metabolizable energy (ME) $/ \mathrm{kg}$ of diet. The diet for grower, phase 1, contained $215 \mathrm{~g} \mathrm{CP}$ and 13.15 MJ ME/kg and for grower, phase 2, $205 \mathrm{~g} \mathrm{CP}$ and $13.31 \mathrm{MJ}$ $\mathrm{ME} / \mathrm{kg}$ of diet while the diet for the finisher phase contained $190 \mathrm{~g} \mathrm{CP}$ and $13.48 \mathrm{MJ} \mathrm{ME} / \mathrm{kg}$ diet. The basal diets (control) were supplemented with four levels of zeolite $(0,1,3$ and $5 \%)$ to provide $0,10,30$ and 50 $\mathrm{g} / \mathrm{kg}$ of total Ca-zeolite in the diet. Feed and water were provided ad libitum.

A broiler house was divided into 12 sections with $2 \times 1 \times 1 \mathrm{~m}$ dimensions (length $\mathrm{x}$ width $\mathrm{x}$ height) and separated by mesh wire fences that prevented air exchange between sections and stocked with 14 birds $/ \mathrm{m}^{2}$. Its preparation was done, as specified by Türkoğlu et al. (1997), prior to the introduction of the chicks. The interior of the broiler house was naturally ventilated. The treatment groups were randomly distributed in the houses and the same airflow was provided. The temperature was maintained at $32{ }^{\circ} \mathrm{C}$ during the first week and was then reduced by $3{ }^{\circ} \mathrm{C}$ per week until $20^{\circ} \mathrm{C}$ was reached. This temperature was maintained until the end of the experiment. The birds were exposed to light for $24 \mathrm{~h}$ during the first three days, and then to $23.5 \mathrm{~h}$ light and $0.5 \mathrm{~h}$ dark daily until slaughter.

At two stages of the study about $5 \mathrm{~mL}$ blood samples were collected from the experimental birds. At the ages of 21 days ( 48 birds) and 42 days ( 48 birds) blood was collected by venipuncture of the wing vein, kept on ice and transferred to the laboratory. Serum was separated and used for biochemical assays. The concentration of serum glucose, cholesterol, total protein, uric acid, $\mathrm{Ca}, \mathrm{P}, \mathrm{Na}, \mathrm{K}$ and $\mathrm{Cl}$ were measured, using commercial kits on an auto-analyzer (Technicon RA-1000).

One set of six males and six females per treatment, 48 birds in total, was selected randomly, and slaughtered at the age of 21 days while another set was slaughtered at the age of 42 days. At slaughter the right tibia bone of each bird was removed as a drumstick with flesh intact. The drumsticks were labelled and immersed in boiling water $\left(100{ }^{\circ} \mathrm{C}\right)$ for $10 \mathrm{~min}$. After cooling to room temperature, the drumstick was defleshed manually and the patella was removed. The bone was then air-dried for $24 \mathrm{~h}$ at room temperature and tibia bone weight was determined. Fat from the tibia was extracted for $16 \mathrm{~h}$ with ethanol, followed by ethyl ether extraction for $16 \mathrm{~h}$ in a Soxhlet apparatus. They were then dried in an oven at $100{ }^{\circ} \mathrm{C}$, and ashed for $6 \mathrm{~h}$ at $600{ }^{\circ} \mathrm{C}$ to measure the fat-free tibia ash content (AOAC, 1995).

Data was analyzed by a completely randomized design within blood and bone groups using the GLM procedure of MINITAB software (Minitab, 2000). Results were presented as mean \pm SEM and differences among treatment means were compared, using the Duncan's multiple-range test.

\section{Results and Discussion}

The data collected at the end of the third and sixth week was evaluated statistically on the serum biochemical parameters (Tables 3 and 4). Serum concentrations of glucose, cholesterol, uric acid, total protein, and some element contents $(\mathrm{Ca}, \mathrm{P}, \mathrm{Na}, \mathrm{K}$ and $\mathrm{Cl})$ did not did differ significantly $(P>0.05)$ between the dietary treatments and the control. It was also evident that the tibia bone parameters (weight, volume, specific gravity, $\mathrm{N}$, ash, $\mathrm{Ca}$, and $\mathrm{P}$ ) in male, female and mixed-sex broilers, were not affected by dietary Cazeolite (Tables 5 and $6 ; P>0.05$ ). However, there have been several reports in the literature indicating a response to zeolites in blood serum and tibia bone parameters of poultry (Elliot et al., 1990; Leach et al., 1990; Park et al., 2002). Our findings were similar to those of Oğuz et al. (2000), who reported that the addition of natural zeolites (clinoptilolite at $1.5 \%$ or $2.5 \%$ ) in the aflatoxin-free diets did not significantly alter the serum biochemical parameters, total protein, glucose, cholesterol, uric acid, Ca and P.

The level of cholesterol in the serum was not affected by dietary treatments (Tables 3 and $4 ; P>0.05$,). The results were in agreement with those in the literature (Dwyer et al., 1997; Keçeci et al., 1998; Curtui, 2000; Lotfollahian et al., 2004; Miles \& Henry, 2007; Safaeikatouli et al., 2011). Altıner et al. (2010) found that the total cholesterol levels of serum in laying hens fed rations with added microbial phytase and supplemented zeolites, were not considerably different. Conversely, Park et al. (2002) indicated that blood cholesterol concentration was significantly lower in 3.0\% natural zeolite treatments than in the control. Curtui (2000) also reported that zeolite supplementation in the diet $(0.5 \%)$ caused a significant decrease in total protein in serum, and an increase in uric acid concentration, whereas some researchers (Lotfollahian et al., 2004; Safaeikatouli et al., 2011) observed increases in the total serum protein concentration by $3 \%$ zeolite supplementation. On the other hand, Pond \& Yen (1983) and Ward et al. (1991) found no effect of 
Na-zeolite A or clinoptilolite on blood urea nitrogen. Our findings are similar to work those of Keçeci et al. (1998), Curtui (2000) and Safaeikatouli et al. (2011), who concluded that glucose levels were not affected by zeolite supplementation. Ledoux et al. (1999) and Miles \& Henry (2007) who used hydrated NaCaaluminosilicate in broiler diets, noted that there was no difference in the glucose components due to dietary treatments. In contrast, Lotfollahian et al. (2004) observed a significant increase in serum glucose concentration at elevated levels of zeolite.

Calcium, $\mathrm{P}, \mathrm{Na}, \mathrm{K}$ and chloride concentrations were within the reference ranges of $9.6-10.5 \mathrm{mg} / \mathrm{dL}$, $7.4-8.9 \mathrm{mg} / \mathrm{dL}, 145.7-154,5.8-9.2$ and $111.7-121.3 \mathrm{mmol} / \mathrm{L}$, respectively, and did not differ between the Ca-zeolite supplemented and control groups (Tables 3 and 4; $P>0.05$ ). Therefore, it could be argued that there was no synergetic or antagonistic relationship between Ca-zeolite levels and the macro-mineral content in broiler feed. Although zeolites could induce alterations in element absorption, such as $\mathrm{Ca}$ and $\mathrm{P}$, and electrolyte balance (Watkins \& Southern, 1991), Ca-zeolite used in this investigation did not negatively affect the balance of serum $\mathrm{Ca}$ and $\mathrm{P}$ concentrations in both sexes and the mixed sex, which is in agreement with the results of Ward et al. (1993) and Frost et al. (1992).

Table 3 The effect of dietary supplementation of different levels of Ca-zeolite on serum biochemical parameters and blood mineral content at three weeks of age

\begin{tabular}{|c|c|c|c|c|c|}
\hline \multirow{2}{*}{ Parameters } & \multicolumn{5}{|c|}{ Groups } \\
\hline & Sex & Control & $1 \%$ Zeolite & 3\% Zeolite & 5\% Zeolite \\
\hline \multirow{3}{*}{$\begin{array}{l}\text { Glucose } \\
(\mathrm{mg} / \mathrm{dL})\end{array}$} & M & $236.3 \pm 5.53$ & $244.7 \pm 18.43$ & $249.7 \pm 2.75$ & $265.5 \pm 16.82$ \\
\hline & $\mathrm{F}$ & $255.0 \pm 15.26$ & $237.2 \pm 14.22$ & $248.3 \pm 9.29$ & $257.0 \pm 16.93$ \\
\hline & Mixed & $245.7 \pm 7.69$ & $240.9 \pm 5.05$ & $249.0 \pm 3.31$ & $261.3 \pm 14.74$ \\
\hline \multirow{3}{*}{$\begin{array}{l}\text { Cholesterol } \\
(\mathrm{mg} / \mathrm{dL})\end{array}$} & M & $118.7 \pm 5.97$ & $147.5 \pm 9.66$ & $135.0 \pm 10.15$ & $120.2 \pm 19.98$ \\
\hline & $\mathrm{F}$ & $109.0 \pm 10.04$ & $123.3 \pm 14.01$ & $123.3 \pm 0.29$ & $122.0 \pm 29.28$ \\
\hline & Mixed & $113.8 \pm 7.88$ & $135.4 \pm 11.54$ & $129.2 \pm 4.96$ & $121.1 \pm 23.06$ \\
\hline \multirow{3}{*}{$\begin{array}{l}\text { Uric acid } \\
\text { (mg/dL) }\end{array}$} & $\mathrm{M}$ & $5.12 \pm 1.01$ & $5.80 \pm 1.03$ & $6.03 \pm 1.51$ & $5.10 \pm 0.80$ \\
\hline & $\mathrm{F}$ & $4.17 \pm 0.46$ & $4.68 \pm 0.03$ & $4.95 \pm 0.33$ & $4.78 \pm 0.30$ \\
\hline & Mixed & $4.64 \pm 0.52$ & $5.24 \pm 0.51$ & $5.49 \pm 0.82$ & $4.94 \pm 0.36$ \\
\hline \multirow{3}{*}{$\begin{array}{l}\text { Total } \\
\text { Protein } \\
(\mathrm{g} / \mathrm{dL})\end{array}$} & M & $2.23 \pm 0.19$ & $2.45 \pm 0.15$ & $2.20 \pm 0.15$ & $2.18 \pm 0.28$ \\
\hline & F & $2.32 \pm 0.16$ & $2.38 \pm 0.14$ & $2.35 \pm 0.13$ & $2.37 \pm 0.28$ \\
\hline & Mixed & $2.28 \pm 0.17$ & $2.42 \pm 0.14$ & $2.28 \pm 0.11$ & $2.28 \pm 0.26$ \\
\hline \multirow{3}{*}{$\begin{array}{l}\text { Calcium } \\
(\mathrm{mg} / \mathrm{dL})\end{array}$} & M & $9.97 \pm 0.10$ & $10.08 \pm 0.23$ & $10.15 \pm 0.56$ & $10.45 \pm 0.44$ \\
\hline & $\mathrm{F}$ & $9.63 \pm 0.23$ & $10.02 \pm 0.42$ & $9.88 \pm 0.26$ & $10.28 \pm 0.34$ \\
\hline & Mixed & $9.80 \pm 0.14$ & $10.05 \pm 0.32$ & $10.02 \pm 0.36$ & $10.37 \pm 0.10$ \\
\hline \multirow{3}{*}{$\begin{array}{l}\text { Phosphorus } \\
\text { (mg/dL) }\end{array}$} & M & $7.82 \pm 0.75$ & $8.38 \pm 0.86$ & $8.57 \pm 0.54$ & $7.58 \pm 0.84$ \\
\hline & $\mathrm{F}$ & $8.00 \pm 0.23$ & $8.63 \pm 0.44$ & $8.43 \pm 0.28$ & $8.88 \pm 0.43$ \\
\hline & Mixed & $7.91 \pm 0.45$ & $8.51 \pm 0.51$ & $8.50 \pm 0.34$ & $8.24 \pm 0.61$ \\
\hline \multirow{3}{*}{$\begin{array}{l}\text { Sodium } \\
(\mathrm{mmol} / \mathrm{L})\end{array}$} & $\mathrm{M}$ & $147.7 \pm 1.04$ & $147.7 \pm 0.76$ & $148.2 \pm 3.75$ & $153.7 \pm 10.32$ \\
\hline & $\mathrm{F}$ & $147.2 \pm 1.53$ & $147.2 \pm 1.04$ & $148.0 \pm 1.73$ & $154.0 \pm 9.18$ \\
\hline & Mixed & $147.4 \pm 0.38$ & $147.4 \pm 0.63$ & $148.1 \pm 2.74$ & $153.8 \pm 9.75$ \\
\hline \multirow{3}{*}{$\begin{array}{l}\text { Potassium } \\
(\mathrm{mmol} / \mathrm{L})\end{array}$} & M & $6.63 \pm 1.01$ & $6.57 \pm 0.93$ & $7.00 \pm 0.40$ & $7.78 \pm 0.55$ \\
\hline & $\mathrm{F}$ & $7.55 \pm 0.44$ & $7.63 \pm 0.91$ & $7.13 \pm 0.63$ & $8.38 \pm 0.73$ \\
\hline & Mixed & $7.09 \pm 0.66$ & $7.10 \pm 0.90$ & $7.07 \pm 0.48$ & $8.09 \pm 0.09$ \\
\hline \multirow{3}{*}{$\begin{array}{l}\text { Chlorine } \\
(\mathrm{mmol} / \mathrm{L})\end{array}$} & M & $114.0 \pm 2.18$ & $113.2 \pm 1.44$ & $113.5 \pm 2.50$ & $118.7 \pm 11.56$ \\
\hline & $\mathrm{F}$ & $112.5 \pm 2.60$ & $111.7 \pm 2.08$ & $115.2 \pm 2.25$ & $121.3 \pm 8.81$ \\
\hline & Mixed & $113.3 \pm 0.25$ & $112.4 \pm 1.42$ & $114.3 \pm 2.10$ & $120.0 \pm 10.18$ \\
\hline
\end{tabular}


In another study it has been reported that serum $\mathrm{Ca}$ concentrations were not affected by dietary zeolites (Alçiçek et al., 1998). Other researchers also demonstrated that using aluminosilicates in dietary rations, had no effect on serum P levels of broiler chicks (Roland et al., 1990; Scheideler, 1993; Dwyer et al., 1997; Ledoux et al., 1999; Lotfollahian et al., 2004). It has been stated that zeolites did not affect serum K and $\mathrm{Na}$ levels, but increased serum $\mathrm{Ca}$ levels (Pond \& Yen, 1983; Roland et al., 1993). Azar et al. (2011) showed that the perlite (aluminosilicate) levels and particle sizes did not affect serum $\mathrm{Ca}, \mathrm{P}, \mathrm{Cl}$ and $\mathrm{Na}$ concentrations. However, they influenced the serum $\mathrm{Mg}$ and $\mathrm{K}$ concentrations appreciably. Similarly, Nazifi et al. (2008) determined that supplementing broiler diets with natural zeolites (1.2\%), had no significant effect on the levels of serum $\mathrm{Na}, \mathrm{K}, \mathrm{Cl}$, and $\mathrm{Mg}$, but that concentrations of serum $\mathrm{Ca}$ and $\mathrm{P}$ showed important changes. On the other hand, Utlu et al. (2007) reported that zeolite supplementation did not affect serum Ca, but $\mathrm{P}$ concentrations decreased significantly in supplemented birds compared to the control. Similarly, Watkins \& Southern (1992) showed large decreases of P concentrations in zeolite-supplemented hens that could be related to the increase of serum Al concentrations. It has been reported that high levels of dietary Al

Table 4 The effect of dietary supplementation of different levels of Ca-zeolite on serum biochemical parameters and blood mineral content at six weeks of age

\begin{tabular}{|c|c|c|c|c|c|}
\hline \multirow{2}{*}{ Parameters } & \multicolumn{5}{|c|}{ Groups } \\
\hline & Sex & Control & $1 \%$ Zeolite & 3\% Zeolite & $5 \%$ Zeolite \\
\hline \multirow{3}{*}{$\begin{array}{l}\text { Glucose } \\
(\mathrm{mg} / \mathrm{dL})\end{array}$} & M & $243.2 \pm 3.25$ & $236.7 \pm 22.77$ & $240.8 \pm 16.59$ & $242.3 \pm 14.01$ \\
\hline & $\mathrm{F}$ & $244.7 \pm 33.65$ & $229.7 \pm 29.19$ & $228.0 \pm 14.80$ & $230.2 \pm 8.43$ \\
\hline & Mixed & $243.9 \pm 18.31$ & $233.2 \pm 25.34$ & $234.4 \pm 14.38$ & $236.3 \pm 8.71$ \\
\hline \multirow{3}{*}{$\begin{array}{l}\text { Cholesterol } \\
\text { (mg/dL) }\end{array}$} & $\mathrm{M}$ & $127.2 \pm 16.92$ & $125.7 \pm 28.01$ & $113.0 \pm 9.00$ & $99.0 \pm 6.26$ \\
\hline & $\mathrm{F}$ & $132.2 \pm 12.85$ & $118.5 \pm 12.01$ & $115.2 \pm 11.73$ & $121.8 \pm 19.05$ \\
\hline & Mixed & $129.7 \pm 14.87$ & $122.1 \pm 19.91$ & $114.1 \pm 10.26$ & $110.4 \pm 12.66$ \\
\hline \multirow{3}{*}{$\begin{array}{l}\text { Uric acid } \\
(\mathrm{mg} / \mathrm{dL})\end{array}$} & $\mathrm{M}$ & $5.42 \pm 1.47$ & $4.87 \pm 1.08$ & $4.22 \pm 1.68$ & $5.12 \pm 0.08$ \\
\hline & $\mathrm{F}$ & $5.88 \pm 1.08$ & $4.90 \pm 1.48$ & $4.78 \pm 1.46$ & $5.68 \pm 0.38$ \\
\hline & Mixed & $5.65 \pm 1.27$ & $4.89 \pm 1.10$ & $4.50 \pm 1.56$ & $5.40 \pm 0.23$ \\
\hline \multirow{3}{*}{$\begin{array}{l}\text { Total } \\
\text { Protein } \\
\text { (g/dL) }\end{array}$} & M & $2.83 \pm 0.67$ & $2.60 \pm 0.35$ & $2.33 \pm 0.06$ & $2.17 \pm 0.25$ \\
\hline & F & $2.65 \pm 0.33$ & $2.58 \pm 0.13$ & $2.63 \pm 0.15$ & $2.53 \pm 0.12$ \\
\hline & Mixed & $2.75 \pm 0.46$ & $2.59 \pm 0.22$ & $2.48 \pm 0.10$ & $2.35 \pm 0.18$ \\
\hline \multirow{3}{*}{$\begin{array}{l}\text { Calcium } \\
(\mathrm{mg} / \mathrm{dL})\end{array}$} & M & $10.30 \pm 0.30$ & $10.35 \pm 0.68$ & $9.95 \pm 0.48$ & $10.02 \pm 0.40$ \\
\hline & $\mathrm{F}$ & $10.18 \pm 0.20$ & $10.35 \pm 0.28$ & $10.22 \pm 0.38$ & $10.02 \pm 0.13$ \\
\hline & Mixed & $10.25 \pm 0.23$ & $10.35 \pm 0.43$ & $10.09 \pm 0.29$ & $10.02 \pm 0.27$ \\
\hline \multirow{3}{*}{$\begin{array}{l}\text { Phosphorus } \\
\text { (mg/dL) }\end{array}$} & M & $7.80 \pm 0.71$ & $8.18 \pm 1.35$ & $8.03 \pm 0.70$ & $7.50 \pm 0.66$ \\
\hline & $\mathrm{F}$ & $7.78 \pm 0.18$ & $8.85 \pm 0.58$ & $7.45 \pm 0.94$ & $7.42 \pm 0.38$ \\
\hline & Mixed & $7.79 \pm 0.39$ & $8.52 \pm 0.97$ & $7.75 \pm 0.23$ & $7.46 \pm 0.45$ \\
\hline \multirow{3}{*}{$\begin{array}{l}\text { Sodium } \\
(\mathrm{mmol} / \mathrm{L})\end{array}$} & M & $149.8 \pm 3.82$ & $149.8 \pm 4.16$ & $145.7 \pm 3.21$ & $146.7 \pm 2.08$ \\
\hline & $\mathrm{F}$ & $148.3 \pm 2.47$ & $150.5 \pm 2.65$ & $146.2 \pm 3.69$ & $146.5 \pm 3.77$ \\
\hline & Mixed & $149.1 \pm 2.90$ & $150.2 \pm 3.40$ & $145.9 \pm 3.45$ & $146.6 \pm 2.92$ \\
\hline \multirow{3}{*}{$\begin{array}{l}\text { Potassium } \\
(\mathrm{mmol} / \mathrm{L})\end{array}$} & M & $7.55 \pm 0.13$ & $5.80 \pm 0.85$ & $9.17 \pm 2.52$ & $7.70 \pm 1.65$ \\
\hline & $\mathrm{F}$ & $7.12 \pm 1.13$ & $6.77 \pm 1.15$ & $7.02 \pm 1.73$ & $8.00 \pm 1.65$ \\
\hline & Mixed & $7.34 \pm 0.58$ & $6.29 \pm 0.99$ & $8.10 \pm 1.98$ & $7.85 \pm 1.46$ \\
\hline \multirow{3}{*}{$\begin{array}{l}\text { Chlorine } \\
(\mathrm{mmol} / \mathrm{L})\end{array}$} & M & $114.7 \pm 3.40$ & $113.5 \pm 1.73$ & $113.3 \pm 1.53$ & $113.5 \pm 0.50$ \\
\hline & $\mathrm{F}$ & $114.7 \pm 1.53$ & $114.7 \pm 1.89$ & $113.5 \pm 1.32$ & $113.8 \pm 2.75$ \\
\hline & Mixed & $114.7 \pm 2.13$ & $114.1 \pm 1.81$ & $113.4 \pm 1.01$ & $113.7 \pm 1.28$ \\
\hline
\end{tabular}


depressed the concentrations of $\mathrm{P}$ and increased the concentration of $\mathrm{Ca}$ in the plasma (Hussein et al., 1990). The expected effects of zeolites might exhibit variation due to factors such as the $\mathrm{Al}$ and $\mathrm{P}$ content of the zeolite, and the level of $\mathrm{Ca}$ and $\mathrm{P}$ in the broiler diets. It could be said that zeolite could not affect the serum $\mathrm{Ca}$ and $\mathrm{P}$ levels in both sex and mixed sex, because the Ca-zeolite used in our study contained high Al levels and the $\mathrm{Si}-\mathrm{Al}$ frame structure of this mineral did not collapse during digestion in the broiler. Apparently, the effects of zeolite supplementation to diets broiler on the blood parameters generally depend on the balance of element content in the diets of broilers.

Table 5 The effect of dietary supplementation of different levels Ca-zeolite on some tibia bone parameters and bone mineral contents at three weeks of age

\begin{tabular}{|c|c|c|c|c|c|}
\hline \multirow{2}{*}{ Parameters } & \multicolumn{5}{|c|}{ Groups } \\
\hline & Sex & Control & $1 \%$ Zeolite & 3\% Zeolite & $5 \%$ Zeolite \\
\hline \multirow{3}{*}{$\begin{array}{l}\text { Calcium } \\
(\mathrm{g} / \mathrm{kg})\end{array}$} & M & $175.8 \pm 4.7$ & $174.5 \pm 7.8$ & $171.1 \pm 8.3$ & $164.9 \pm 7.4$ \\
\hline & F & $168.5 \pm 4.9$ & $171.3 \pm 0.9$ & $172.9 \pm 3.0$ & $164.5 \pm 5.8$ \\
\hline & Mixed & $172.1 \pm 1.0$ & $172.9 \pm 4.0$ & $172.0 \pm 5.6$ & $164.7 \pm 1.5$ \\
\hline \multirow{3}{*}{$\begin{array}{l}\text { Phosphorus } \\
(\mathrm{g} / \mathrm{kg})\end{array}$} & M & $86.0 \pm 1.0$ & $83.9 \pm 3.3$ & $84.3 \pm 3.8$ & $78.9 \pm 4.9$ \\
\hline & $\mathrm{F}$ & $83.1 \pm 3.0$ & $80.3 \pm 5.6$ & $84.7 \pm 0.9$ & $80.0 \pm 2.8$ \\
\hline & Mixed & $84.5 \pm 1.1$ & $82.1 \pm 4.3$ & $84.5 \pm 2.2$ & $79.4 \pm 3.6$ \\
\hline \multirow{3}{*}{ Ash (g/kg) } & M & $451.4 \pm 10.1$ & $451.8 \pm 22.1$ & $447.2 \pm 5.9$ & $458.5 \pm 7.5$ \\
\hline & $\mathrm{F}$ & $441.8 \pm 19.0$ & $448.6 \pm 7.3$ & $454.3 \pm 7.8$ & $435.8 \pm 11.1$ \\
\hline & Mixed & $446.5 \pm 4.6$ & $450.3 \pm 7.6$ & $450.8 \pm 6.1$ & $447.2 \pm 7.6$ \\
\hline \multirow{3}{*}{$\begin{array}{l}\text { Nitrogen } \\
(\mathrm{g} / \mathrm{kg})\end{array}$} & M & $50.0 \pm 2.6$ & $48.7 \pm 2.2$ & $50.2 \pm 3.1$ & $49.1 \pm 1.4$ \\
\hline & $\mathrm{F}$ & $49.3 \pm 1.9$ & $47.2 \pm 2.5$ & $48.1 \pm 3.1$ & $46.4 \pm 2.1$ \\
\hline & Mixed & $49.7 \pm 2.3$ & $47.9 \pm 2.4$ & $49.1 \pm 3.1$ & $47.7 \pm 0.7$ \\
\hline \multirow{3}{*}{ Weight (g) } & M & $2.28 \pm 0.10$ & $2.26 \pm 0.21$ & $2.44 \pm 0.23$ & $2.35 \pm 0.09$ \\
\hline & $\mathrm{F}$ & $2.20 \pm 0.32$ & $1.98 \pm 0.21$ & $2.09 \pm 0.38$ & $2.18 \pm 0.15$ \\
\hline & Mixed & $2.24 \pm 0.19$ & $2.12 \pm 0.20$ & $2.27 \pm 0.08$ & $2.26 \pm 0.09$ \\
\hline \multirow{3}{*}{$\begin{array}{l}\text { Volume } \\
\left(\mathrm{cm}^{3}\right)\end{array}$} & $\mathrm{M}$ & $2.42 \pm 0.14$ & $2.67 \pm 0.14$ & $2.58 \pm 0.38$ & $2.58 \pm 0.14$ \\
\hline & F & $2.25 \pm 0.50$ & $2.08 \pm 0.29$ & $2.42 \pm 0.38$ & $2.42 \pm 0.14$ \\
\hline & Mixed & $2.34 \pm 0.19$ & $2.38 \pm 0.21$ & $2.50 \pm 0.00$ & $2.50 \pm 0.13$ \\
\hline \multirow{3}{*}{$\begin{array}{l}\text { Specific } \\
\text { gravity } \\
\left(\mathrm{g} / \mathrm{cm}^{3}\right)\end{array}$} & M & $0.95 \pm 0.04$ & $0.85 \pm 0.03$ & $0.96 \pm 0.07$ & $0.91 \pm 0.02$ \\
\hline & F & $0.92 \pm 0.14$ & $0.97 \pm 0.07$ & $0.86 \pm 0.04$ & $0.90 \pm 0.01$ \\
\hline & Mixed & $0.94 \pm 0.08$ & $0.91 \pm 0.02$ & $0.91 \pm 0.04$ & $0.90 \pm 0.01$ \\
\hline
\end{tabular}

There was no significant effect on tibia bone parameters, tibia bone weight, ash and Ca concentrations due to the various types and levels of Ca-zeolite used during both periods. It has been reported that an increase in the tibia ash content was a useful indicator in the evaluation of bone mineralization in poultry (Ahmad et al., 2000; Abas et al., 2011). Similarly, Moghadam et al. (2005) claimed that the use of zeolites in diets did not have any considerable effect on the apparent digestibility of $\mathrm{Ca}$ and tibia ash content. Our findings were contrary to those of Elliot et al. (1990) and Leach et al. (1990) who mentioned that zeolites had beneficial effects on bone ash and strength, but no effect on tibial dychondroplasia. Ballard \& Edwards (1988) reported that $1 \%$ zeolite supplementation in broiler diets containing $0.65 \% \mathrm{Ca}$, increased tibia ash content significantly. Yalçın et al. (1995) observed a similar influence of added zeolites on the bone ash of broilers. Although tibial dyschondroplasia is a metabolic cartilage disease representing the endpoint of several mechanisms, the incidence seemed to increase when high dietary levels of P were fed (Edwards, 1984) or when dietary Ca was lower than $0.85 \%$ (Edwards, 1988; Leach et al., 1990; Ledwaba \& Roberson, 
2003). Furthermore, high levels of $\mathrm{Ca}$ in broiler diets were proven to decrease feed consumption and the toxic effects (Shafey et al., 2011).

It has been signified that the addition of zeolites to broiler diets increased the level of the tibia bone ash (Watkins \& Southern, 1991). As a matter of fact, the beneficial effect of zeolite A has been inconsistent and largely dependent on the dietary level of $\mathrm{Ca}$. The dietary inclusion of synthetic zeolite A (at $0.75 \%$ or $1.5 \%$ ), when broilers were on a diet with inadequate or marginal levels of Ca resulted in an increase in bone ash content along with a reduction of rachitic lesions (Leach et al., 1990). According to Watkins \& Southern (1991), the dietary use of $0.75 \%$ zeolite A in broilers is accompanied by alterations in mineral absorption and tissue distribution, resulting in an increased tibia ash content and density and improved fresh tibia shearing force scores, but only when dietary calcium ranged from $0.6 \%$ to $0.8 \%$ (Papaioannou et al., 2005).

Table 6 The effect of dietary supplementation of different levels of Ca-zeolite on some tibia bone parameters and bone mineral content at six weeks of age

\begin{tabular}{lcrrrr}
\hline \multirow{2}{*}{ Parameters } & \multicolumn{5}{c}{ Groups } \\
\cline { 2 - 6 } & Sex & \multicolumn{1}{c}{ Control } & $1 \%$ Zeolite & \multicolumn{1}{c}{$3 \%$ Zeolite } & $5 \%$ Zeolite \\
\hline Calcium & M & $139.9 \pm 7.7$ & $136.3 \pm 8.2$ & $148.0 \pm 10.1$ & $148.7 \pm 17.6$ \\
$(\mathrm{~g} / \mathrm{kg})$ & $\mathrm{F}$ & $150.6 \pm 11.4$ & $146.9 \pm 6.0$ & $139.0 \pm 6.8$ & $149.6 \pm 15.8$ \\
& Mixed & $145.2 \pm 9.6$ & $141.6 \pm 7.0$ & $143.5 \pm 8.2$ & $149.2 \pm 16.5$ \\
Phosphorus & $\mathrm{M}$ & $63.9 \pm 2.8$ & $67.5 \pm 3.7$ & $72.6 \pm 4.7$ & $72.4 \pm 8.4$ \\
(g/kg) & $\mathrm{F}$ & $74.0 \pm 4.9$ & $71.3 \pm 2.7$ & $68.2 \pm 3.5$ & $73.3 \pm 8.2$ \\
& Mixed & $68.9 \pm 1.1$ & $69.3 \pm 3.2$ & $70.5 \pm 3.9$ & $72.8 \pm 8.3$ \\
& $\mathrm{M}$ & $380.3 \pm 12.8$ & $360.4 \pm 16.1$ & $380.1 \pm 18.3$ & $392.1 \pm 35.6$ \\
Ash $(\mathrm{g} / \mathrm{kg})$ & $\mathrm{F}$ & $401.5 \pm 27.6$ & $390.1 \pm 8.4$ & $366.5 \pm 27.5$ & $404.2 \pm 24.8$ \\
& Mixed & $390.9 \pm 19.0$ & $375.2 \pm 12.1$ & $373.3 \pm 21.0$ & $398.1 \pm 28.3$ \\
Nitrogen & $\mathrm{M}$ & $39.5 \pm 2.0$ & $40.7 \pm 0.7$ & $42.5 \pm 5.0$ & $41.8 \pm 5.6$ \\
$(\mathrm{~g} / \mathrm{kg})$ & $\mathrm{F}$ & $40.6 \pm 4.2$ & $39.7 \pm 3.1$ & $43.1 \pm 6.5$ & $42.1 \pm 1.9$ \\
& Mixed & $40.1 \pm 1.8$ & $40.1 \pm 1.8$ & $42.8 \pm 4.4$ & $41.9 \pm 3.8$ \\
Weight $(\mathrm{g})$ & $\mathrm{M}$ & $7.43 \pm 0.33$ & $7.18 \pm 0.33$ & $7.03 \pm 0.37$ & $7.36 \pm 0.16$ \\
& $\mathrm{~F}$ & $6.22 \pm 0.20$ & $6.29 \pm 0.41$ & $6.63 \pm 0.26$ & $6.41 \pm 0.17$ \\
& Mixed & $6.83 \pm 0.15$ & $6.74 \pm 0.32$ & $6.83 \pm 0.19$ & $6.89 \pm 0.17$ \\
Volume & $\mathrm{M}$ & $7.92 \pm 0.38$ & $7.67 \pm 0.14$ & $7.50 \pm 0.87$ & $7.67 \pm 0.72$ \\
$\left.(\mathrm{~cm})^{3}\right)$ & $\mathrm{F}$ & $6.08 \pm 0.38$ & $6.33 \pm 0.63$ & $5.75 \pm 0.43$ & $5.58 \pm 0.88$ \\
& Mixed & $7.00 \pm 0.38$ & $7.00 \pm 0.33$ & $6.63 \pm 0.57$ & $6.63 \pm 0.25$ \\
Specific & $\mathrm{M}$ & $0.94 \pm 0.04$ & $0.94 \pm 0.05$ & $0.95 \pm 0.13$ & $0.97 \pm 0.10$ \\
Gravity & $\mathrm{F}$ & $1.00 \pm 0.10$ & $1.01 \pm 0.17$ & $1.16 \pm 0.09$ & $1.17 \pm 0.15$ \\
$\left(\mathrm{~g} / \mathrm{cm}^{3}\right)$ & Mixed & $0.97 \pm 0.07$ & $0.98 \pm 0.10$ & $1.06 \pm 0.09$ & $1.07 \pm 0.03$ \\
& & & & & \\
\hline
\end{tabular}

In another study it has been claimed that the addition of zeolites increased $\mathrm{Ca}$ utilization and the content of bone ash during growth (Watkins \& Southern, 1992). Gezen \& Eren (2002) pointed out that zeolite supplementation (2\%) to broiler diets resulted in a reduction of incidence and severity of tibial dyschondroplasia at 21 days of age. On the other hand, Rabon et al. (1995) claimed that using zeolites in the diet had some effect on tibia ash, while others reported no such effect (Elliot \& Edwards, 1991; Keshavarz \& Mccormick, 1991; Altan et al., 1998). A few writers (Pond et al., 1988; Safaeikatouli et al., 2010) suggested that the structure of the mineral, the geographical source of the involved zeolite, or its unique crystal structure, size, shape of cavities, porosity and the metal oxide content as well as environmental conditions and animal species, could be responsible for these inconsistent findings. 


\section{Conclusion}

The results of this experiment suggested that additional Ca-zeolites $(1,3,5 \%)$ in diets did not have any adverse effects on blood and bone characteristics of broiler males and females. Furthermore, at 5\% inclusion of Ca-zeolite, broilers did not exhibit any negative response in terms of health status or cost of feeding. In conclusion, the findings showed that the addition of Ca-zeolites to broiler diets was generally acceptable and had no detrimental effects on the parameters monitored.

Additional experiments are needed to determine the effect of zeolites at different testing conditions, on natural zeolite types with different elemental ratios $(\mathrm{Si} / \mathrm{Al}+\mathrm{Fe}$, alkali/alkaline-earth, $\mathrm{Na} / \mathrm{K})$ and various adsorptive abilities of zeolites in broilers.

\section{Acknowledgements}

The authors are very grateful to the Scientific Research Project Fund of the Cumhuriyet University under the project number ENF-001 for their financial support. We would also like to express our thanks to Ahmet Aker for making the laboratory facilities available. Thanks also go to the anonymous reviewers and Editorial Board whose helpful reviews of the manuscript have greatly improved it.

\section{References}

Abas, İ., Bilal, T., Ercag, E. \& Keser, O., 2011. The effect of organic acid and zeolite addition alone and in combination on the bone mineral value in broilers fed different dietary phosphorus levels. Asian J. Anim. Vet. Adv. 6, 678-687.

Ahmad, T., Rasool, S., Sarwar, M., Haq, A.U. \& Hasan, Z.U., 2000. Effect of microbial phytase produced from a fungus Aspergillus niger on bioavailability of phosphorus and calcium in broiler chickens. Anim. Feed Sci. Technol. 83, 103-114.

Alçiçek, A., Bozkurt, M., Özkan, K., Altan, A., Çabuk, M., Akbaş, Y. \& Altan, Ö., 1998. Utilization of natural zeolite in poultry. II. Effect of zeolite supplementation on broiler performance, some tibia and blood serum parameters. Aegean Univ. J. Agric. Fac. 35, 17-24.

Altan, A., Altan, Ö., Alçiçek, A., Nalbant, M. \& Akbaş, Y., 1998. Utilization of natural zeolite in poultry. I. Effects of adding zeolite to litter on broiler performance, litter moisture and ammonia concentration. Aegean Univ. J. Agric. Fac. 35, 9-16.

Altıner, A., Bilal, T., Eseceli, H. \& Gürsel, F.E., 2010. Effect of vitamin D3 and/or zeolite supplementation to laying hen rations added microbial phytase on some blood indices 2. Total cholesterol, 1, 25dihydroxycholecalciferol and oestradiol-17ß levels. Kafkas Univ. J. Vet. Fac. 16, 419-424.

AOAC, 1995. Association of Official Analytical Chemists. 13th ed. Official Method of Analysis. Washington, D.C., USA.

Azar, H.R.E., Adl, K.N., Nezhad, Y.E. \& Moghaddam, M., 2011. Effect of different levels and particle sizes of perlite on serum biochemical factors of broiler chicks. Afr. J. Biotechnol. 10, 3232-3236.

Ballard, R. \& Edwards Jr, H.M., 1988. Effects of dietary zeolite and vitamin A on tibial dyschondroplasia in chickens. Poult. Sci. 67, 113-119.

Başalan, M., Güngör, T., Aydoğan, I., Hışmığulları, S.E., Erat, S. \& Erdem, E., 2005. Effects of adding HSCAS to broiler diets prior to slaughter on performance, digestive system $\mathrm{pH}$ 's and blood biochemistry. National Animal Nutrition Congress III, September 7-10, Adana. pp. 374-377.

Curtui, V.G., 2000. Effects of feeding a Fusarium poae extract and a natural zeolite to broiler chickens. Mycotoxin Res. 16, 43-52.

Debeic, M., 1994. Influence of clinoptilolites on chicken growth. Abstract. Poult. 21, 309.

Dwyer, M.R., Kubena, L.F., Harvey, R.B., Mayura, K., Sarr, A.B., Buckley, S., Bailey, R.H. \& Phillips, T.D., 1997. Effect of inorganic adsorbents and cyclopiazonic acid in broiler chicken. Poult. Sci. 76, 1141-1149.

Edwards Jr., H.M., 1984. Studies on the etiology of tibial dyschondroplasia in chickens. J. Nutr. 114, 1001-1013.

Edwards Jr., H.M., 1987. Response of broilers to zeolite in the feed when dietary calcium, phosphorus and chloride vary. Proc. Georgia Nutr. Conf., University of Georgia, Athens, G.A. pp. 129-139.

Edwards Jr., H.M., 1988. Effect of dietary calcium, phosphorus, chloride and zeolite on the development of tibial dyschondroplasia. Poult. Sci. 67, 1436-1446. 
Eleroğlu, H. \& Yalçın, H., 2005. Use of natural zeolite-supplemented litter increased broiler production. S. Afr. J. Anim. Sci. 35, 90-97.

Elliot, M.A. \& Edwards Jr, H.M., 1991. Some effects of dietary aluminum and silicon in broiler chickens. Poult. Sci. 70, 1390-1402.

Elliot, M.A., Edwards, B.S. \& Burdette, J., 1990. Comparison of the effect of synthetic and natural zeolite on laying and broiler chickens performance. Poult. Sci. 70, 2115-2130.

Eraslan, G., Eşsiz, D., Akdoğan, M., Şahindokuyucu, F. \& Altıntaş, L., 2005. The effects of aflatoxin and sodium bentonite combined and alone on some blood electrolyte levels in broiler chickens. Turkish J. Vet. Anim. Sci. 29, 601-605.

Frost, T.J., Roland, D.A., Barnes, D.G. \& Laurent, S.M., 1992. The effect of sodium zeolite A and cholecalciferol on plasma levels of 1,25 dihydroxycholecalciferol, Ca, and P in commercial Leghorns. J. Poult. Sci. 71, 886-893.

Gezen, Ş.Ş. \& Eren, M., 2002. The effect of interaction between narasin and nicarbazin with zeolite supplemented to mixed feed on small intestine weight and tibial dyschondroplasia, tibia ash and blood parameters of broiler chickens. Uludağ Univ. J. Fac. Vet. Med. 21, 49-57.

Hussein, A.S., Cantor, A.H. \& Johnson, T.H., 1990. Relationship of dietary aluminum, phosphorus and calcium to phosphorus and calcium metabolism of broiler chicks. Poult. Sci. 69, 966-971.

Jain, S.K., 1999. Protective role of zeolite on short- and long-term lead toxicity in the teleost fish Heteropneustes fossilis. Chemosphere 39, 247-251.

Keçeci, T., Oğuz, H., Kurtoğlu, V. \& Demet, Ö., 1998. Effects of polyvinylpolypyrrolidone, synthetic zeolite and bentonite on serum biochemical and haematological characters of broiler chickens during aflatoxicosis. Br. Poult. Sci. 39, 452-458.

Keshavarz, K. \& Mccormick, C.C., 1991. Effect of sodium aluminosilicate oyster shell and their combinations on acid-base balance and eggshell quality. Poult. Sci. 70, 313-325.

Kurtoğlu, F., Başpınar, N. \& Haliloğlu, S., 1998. Effects of sodium aluminosilicate (zeolite) supplemented in diets on plasma mineral composition in broilers. J. Lalahan Res. Ins. 8, 90-93.

Leach Jr., R.M., Hemrichs, B.S. \& Burdette, J., 1990. Broiler chicks fed low calcium diets. I. Influence of zeolite on growth rate and parameters of bone metabolism. Poult. Sci. 69, 1539-1543.

Ledoux, D.R., Rottinghaus, G.E., Bermudez, A.J. \& Alonso-Debolt, M., 1999. Efficacy of a hydrated sodium calcium aluminosilicate to ameliorate the toxic effects of aflatoxin in broiler chicks. Poult. Sci. 78, 204-210.

Ledwaba, M.F. \& Roberson, K.D., 2003. Effectiveness of 25-hydroxycholecalciferol in the prevention of tibial dyschondroplasia in Ross cockerels depends on dietary calcium level. Poult. Sci. 82, 1769-1777.

Lotfollahian, H., Shariatmadari, F., Shivazad, M. \& Mirhadi, S.A., 2004. Study on the effects of two kinds of natural zeolite in diets on blood biochemical parameters, relative weight of body organs and broilers performance. Pajouhesh and Sazandegi 64, 18-34.

Miles, R.D. \& Henry, P.R., 2007. Safety of improved Milbond-TX ${ }^{\circledR}$ when fed in broilers diets at greater than recommended levels. Anim. Feed Sci. Technol. 138, 309-317.

Minitab, 2000. Minitab Statistical Software User's Guide 2: Data Analysis and Quality Tools. Minitab Inc., State College, PA. www.minitab.com.

Moghadam, H.N., Rezaei, M. \& Abadi, A.H., 2005. Effect of natural zeolite on performance, and tibia composition of broiler chicks. Proc. XVII European Symposium on the Quality of Poultry Meat and XI European Symposium on the Quality of Eggs and Egg Products, Golden Tulip Parkhotel, Doorwerth, Netherlands, 23-26 May. pp. 361.

Mumpton, F.A., 1999. La roca magica: Uses of natural zeolites in agriculture and industry. Proc. Natl. Acad. Sci. 96, 3463-3470.

Mumpton, F.A. \& Fishman, P.H., 1977. The application of natural zeolites in animal science and aquaculture. J. Anim. Sci. 45, 1188-1203.

Nakaue, H.S., Koellike, J.K. \& Pierson, M.L., 1981. Studies with clinoptilolite in Poultry. 2. Effect of feeding broilers and the direct application of clinoptilolite (zeolite) on clean and re-used broiler performance and houses environment. Poult. Sci. 60, 1221-1225.

Nazifi, S., Dadras, H.A. \& Afsaneh, K., 2008. The effect of zeolite on serum electrolytes of broiler chickens. Sci.-Res. Iranian Vet. J. 4, 85-93.

NRC, 1994. Nutrient Requirements of Poultry (9th ed), National Academy Press, Washington, D.C., USA. 
Oğuz, H., Keçeci, T., Birdane, Y.O., Önder, F. \& Kurtoğlu, V., 2000. Effect of clinoptilolite on serum biochemical and haematological characters of broiler chickens during aflatoxicosis. Res. Vet. Sci. 69, 89-93.

Öztürk, E., Erenler, G. \& Sarıca, M., 1998. Influence of natural zeolite on performance of laying hens and egg quality. Turkish J. Agric. Forestry 22, 623-628.

Papaioannou, D., Katsoulos, P.D., Panousis, N. \& Karatzias, H., 2005. The role of natural and synthetic zeolites as feed additives on the prevention and/or the treatment of certain farm animal diseases: A review. Micropor. Mesopor. Mater. 84,161-170.

Park, J.H., Lee, D.B., Kim, S.H., Shin, W.J. \& Ryu, K.S., 2002. Effect of dietary supplementation of artificial and natural zeolites on performance and intestinal microbes of broiler chicks. Korean J. Poult. Sci. 29, 101-107.

Pond, W.G. \& Yen, J.T., 1983. Protection by clinoptilolite or zeolite NaA against cadmium-induced anemia in growing swine. Proc. Soc. Exper. Biol. Med. 173, 327-337.

Pond, W., Yen, G.J.T. \& Varel, V.H., 1988. Response of growing swine to dietary copper and clinoptilolite supplementation. Nutr. Rep. Int. 37, 797-803.

Quarles, C.L., 1985. Zeolites, a new ingredient may cut costs in poultry production. Feedstuffs 7, 35-36.

Rabon, H.W., Roland, D.A., Bryant, M.M., Smith, R.C., Barnes, D.G. \& Laurent, S.M., 1995. Absorption of silicon and aluminum by hens fed sodium zeolite A with various levels of dietary cholecalciferol. Poult. Sci. 74, 352-359.

Roland, D.A., Laurent, S.M. \& Orloff, H.D., 1985. Shell quality as influenced by zeolite with high ionexchange capability. Poult. Sci. 64, 1177-1187.

Roland, D.A., Rabon, H.W., Frost, T.J., Laurent, S.M. \& Barnes, D.G., 1990. Response of commercial Leghorns to sodium aluminosilicates when fed different levels and sources of available phosphorous. J. Poult. Sci. 69, 2157-2164.

Roland, D.A., Rabon, H.W., Rao, K.S., Smith, R.C., Miller, J.W., Barnes, D.G. \& Laurent, S.M., 1993. Evidence for absorption of silicon and aluminum by hens fed sodium zeolite. Poult. Sci. 72, 447-455.

Safaeikatouli, M., Boldaji, F., Dastar, B. \& Hassani, S., 2010. Effect of different levels of kaolin, bentonite and zeolite on broilers performance. J. Biol. Sci. 10, 58-62.

Safaeikatouli, M., Jafariahangari, Y. \& Baharlouei, A., 2011. An evaluation on the effects of dietary kaolin and zeolite on broilers blood parameters, T4, TSH and growth hormones. Pakistan J. Nutr. 10, 233-237.

Santurio, J.M., Mallmann, C.A., Rosa, A.P., Appel, G., Heer, A., Dageforde, S. \& Bottcher, M., 1999. Effect of sodium bentonite on the performance and blood variables of broiler chickens intoxicated with aflatoxins. Br. Poult. Sci. 40, 115-119.

Scheideler, S.E., 1993. Effect of various types of aluminosilicates and aflatoxin $\mathrm{B}_{1}$ on aflatoxin toxicity, chick performance and mineral status. Poult. Sci. 72, 282-288.

Shafey, T.M., Aljumaah, R.S., Abdelhalim, M.A.K., Mady, M.M. \& Ghannam, M.M., 2011. Effects of dietary electrolyte balance on the performance of broiler chickens fed high calcium diets. J. Anim. Vet. Adv. 10, 2902-2908.

Shariatmadari, F., 2008. The application of zeolite in poultry production. Wrld Poult. Sci. 64, 76-84.

Tauqir, N.A. \& Nawaz, H., 2001. Performance and economics of broiler chicks fed on rations supplemented with different levels of sodium bentonite. Int. J. Agric. Biol. 3, 149-150.

Tauqir, N.A., Sultan, J.I. \& Navaz, H., 2001. Effect of different levels of bentonite with varying energy levels on the performance of broilers. Int. J. Agric. Biol. 3, 85-88.

Tiwari, J., 2007. Zeolite as natural feed additives to reduce environmental impacts of swine manure. M.Sc. thesis, McGill University, Montreal, Canada. 100 pp.

Türkoğlu, M., Arda, M., Yetişir, R., Sarıca, M. \& Erensayın, C., 1997. Broiler production. Poultry Science, Otak Form-Ofset, Samsun. pp.167-185 (in Turkish).

Utlu, N., Çelebi, S. \& Yücel, O., 2007. The Effects of natural zeolite supplementation to diet on serum element concentrations in laying hens. Revue Med. Vet. 158, 598-602.

Waldroup, P.W., Spencer, G.K. \& Smith, N.K., 1984. Evaluation of zeolites in the diet of broiler chickens. Poult. Sci. 63, 1833-1836. 
Ward, T.L., Watkins, K.L., Southern, L.L., Hoyt, P.G. \& French, D.D., 1991. Interactive effects of sodium zeolite A and copper in growing swine: Growth, and bone and tissue mineral concentrations. J. Anim. Sci. 69, 726-733.

Ward, T.L., Watkins, K.L. \& Southern, L.L., 1993. Research Note: Interactive effects of sodium zeolite A and Eimeria acervulina infection on growth and tissue minerals in chicks. Poult. Sci. 72, 2172-2175.

Watkins, K.L. \& Southern, L.L., 1991. Effect of dietary sodium zeolite A and graded levels of calcium on growth, plasma, and tibia characteristics of chicks. Poult. Sci. 70, 2295-2303.

Watkins, K.L. \& Southern, L.L., 1992. Effect of dietary sodium zeolite A and graded levels of calcium and phosphorus on growth, plasma, and tibia characteristics of chicks. Poult. Sci. 71, 1048-1058.

Yalçın, H., 1997. Central North Anatolian zeolite occurrences related to Eocene submarine volcanism in Turkey. Bull. Eng. Fac. Cumhuriyet Univ. Serie A-Earth Sci. 14, 43-56 (in Turkish, English abstract).

Yalçın, S., Bilgili, S.F. \& McDaniel, G.R., 1995. Sodium zeolite A: Influence on broiler carcass yield and tibia characteristics. J. Appl. Poult. Sci. 4, 61-68.

Zhang, N.Z. \& Hung, R.L., 1992. Study on feeding broilers with natural zeolite. Anim. Sci. 15, 71-74. 